\title{
Microbial, biochemical and sensorial quality assessment of Algerian farmed tilapia (Oreochromis niloticus) stored at 4 and $30^{\circ} \mathrm{C}$
}

\author{
Dergal N. B. ${ }^{1,2 \star}$, Abi-Ayad S. M. E. A. ${ }^{2}$, Degand G. ${ }^{1}$, Douny C. $^{1}$, Brose F. ${ }^{1}$, Daube G. ${ }^{3}$, \\ Rodrigues $A^{3}$ and Scippo M. L.
}

${ }^{1}$ Laboratory of Food Analysis, Department of Food Sciences, Faculty of Veterinary Medicine, University of Liège, bât. B43bis, Bld de Colonster 20, Sart-Tilman, B-4000 Liège, Belgium.

${ }^{2}$ Laboratory of Aquaculture and Bioremediation (AquaBior), Department of Biotechnology, Faculty of Natural and Life Sciences, University of Oran, B.P. 1524, El M'Naouer, Oran 31000, Algeria.

${ }^{3}$ Laboratory of Food Microbiology, Department of Food Sciences, Faculty of Veterinary Medicine, University of Liège, bât. B43 bis, Bld de Colonster 20, Sart-Tilman, B-4000 Liège, Belgium.

Accepted 30 October, 2013

\begin{abstract}
The quality of Nile tilapia (Oreochromis niloticus) produced in Algeria was assessed after refrigerated $\left(4^{\circ} \mathrm{C}\right)$ storage as well as ambient temperature $\left(30^{\circ} \mathrm{C}\right)$ keeping, corresponding to usual fish selling conditions in Algeria. Sensorial, microbial and biochemical analyzes were conducted in parallel. Moreover, the nutritional quality of fresh tilapia was also assessed by determining the proximate composition and the fatty acids profile. Results of lipid oxidation, namely hydroperoxydes and thiobarbituric acid-reactive substances (TBARS), proteolysis, represented by total volatile basic nitrogen (TVB-N) and trimethylamine (TMA-N), sensory assessment and bacterial load were highly correlated. They demonstrated that the shelf life of tilapia is limited to $12 \mathrm{~h}$ and five days of storage at 30 and $4^{\circ} \mathrm{C}$ respectively. After these period of time, fish was rejected by sensorial analysis and all the parameters thresholds (fixed in the present study at $0.85 \mathrm{mg} \mathrm{MDA} \mathrm{kg}^{-1}$ of wet weight for TBARS, $35 \mathrm{mg}$ TVB-N $100 \mathrm{~g}^{-1}$ of flesh, $8 \mathrm{mg}$ TMA-N $100 \mathrm{~g}^{-1}$ of flesh and $6 \log \mathrm{cfu} \mathrm{g}^{-1}$ for total viable count) were exceeded.
\end{abstract}

Key words: Shelf life, Oreochromis niloticus, fatty acid profile, thiobarbituric acid-reactive substances (TBARS), trimethylamine (TMA), hydroperoxides.

\section{INTRODUCTION}

In Algeria, aquaculture has clearly evolved and become a priority of the government to offset the deficit of fishery products. New continental freshwater species such as Nile tilapia (Oreochromis niloticus) were introduced. The intensive farming of tilapia, Oreochromis sp. is rapidly expanding and tilapias are the second most widely farmed fish in the world with annual production exceeding 3 million tons in 2010 (FAO, 2012).
Tilapias have many attributes that make them an ideal candidate for promo-ting aquaculture and provide sustainable development in Algeria. These include: fast growth, tolerance to a wide range of environmental conditions, resistance to stress and disease, ability to reproduce in captivity, feeding on low trophic levels and good sensorial proprieties of flesh (Boari et al., 2008). Freshwater fish represent an important source of high- 
quality proteins and other elements for human nutrition (Dhanapal et al., 2012; Navarro, et al., 2012). However, fresh fish is a highly perishable product (Gram and Huss, 1996). Immediately after its death, the fish undergo a natural and complex decomposition process, that is, microbial, chemical and enzymatic (Huss, 1995). The freshness of fish is reduced by the oxidative rancidity (Azhar and Nisa, 2006), the organoleptic properties are rapidly deteriorated, the nutritional value is reduced and toxic substances are formed (Huss, 1995).

Fish lipids are characterized by their high content of polyunsaturated fatty acids (PUFA) of $\omega 3$ series such as eicosapentaenoïc (EPA C20:5 n-3) and docosahexaenoïc acid (DHA C22:6 n-3). However, these lipids are very susceptible to oxidation reactions (Ozogul et al., 2011). These reactions lead to the formation of primary products such as hydroperoxides, which are very unstable compounds quickly transformed into secondary products such as toxic aldehydes (Rezaei and Hosseini, 2008), measurable as thiobarbituric acid-reactive substances (TBARS) (Yarnpakdee et al., 2012). In addition, the shelflife of fresh fish is usually limited by bacterial activity and/or enzymatic degradation of trimethylamine oxide (TMAO) (Gram and Dalgaard, 2002). The specific spoilage organisms (SSO) utilize the available TMAO in anaerobic respiration and produces off-odors following the formation of TMA (Gram and Huss, 1996). Marine fish and some freshwater fish such as tilapia (Niizeki et al., 2003) contain TMAO. Trimethylamine (TMA), ammonia $\left(\mathrm{NH}_{3}\right)$ and dimethylamine (DMA) as well as levels of total volatile basic nitrogen (TVB-N), are useful indices of fish freshness (Ozogul et al., 2005). The TVB-N parameter represents a quality index of fish and reflects its bacterial and enzymatic proteolysis (Zhou et al., 2011). Temperature is the main environmental factor that affects growth and viability of SSO and consequently determines fish shelf life.

This work aimed at chemical, microbial and sensory assessment of the Algerian farmed tilapia under refrigerated $\left(4^{\circ} \mathrm{C}\right)$ and ambient $\left(30^{\circ} \mathrm{C}\right)$ storage conditions, the later been usual conditions of fish selling in local Algerian markets. Furthermore, this study provides information on fatty acids profile and macronutrients composition of fresh raw tilapia to characterize its nutritional quality.

\section{MATERIALS AND METHODS}

\section{Sampling}

A total of 136 farmed tilapia (O. niloticus) were obtained from a local aquafarm "Fat-Step", $250 \mathrm{~km}$ from south west of Oran (ALGERIA), and brought alive to the faculty's laboratory (Laboratory of Aquaculture and Bioremediation- AquaBior). Fish were of comercial size (correspondent to 5 months of breeding) and weighing 120-160 g. They were not separated according to gender. Upon arrival, tilapias were divided into two batches and sacrificed using a lethal dose (200 mg l$~^{-1}$ ) of anaesthetic (Benzocaïne, Sigma). The first lot was stored in the refrigerator at $4^{\circ} \mathrm{C}$ and the second lot was kept in plastic box at ambient temperature $\left(30^{\circ} \mathrm{C}\right)$.
Sampling procedure was carried out two times in order to assess all the biochemical, microbiological, nutritional and sensory parameters. A first sampling of 95 tilapias was needed to evaluate oxidation reactions (TBARS and hydroperoxides measurement). For the first $12 \mathrm{~h}$, five samples were taken at $3 \mathrm{~h}$ intervals from both studied batches. Then, a daily interval of sampling $(n=5)$ was planned until the third day for the ambient lot $\left(30^{\circ} \mathrm{C}\right)$ and the seventh day for the refrigerated one $\left(4^{\circ} \mathrm{C}\right)$. Thereafter, 36 tilapias were sampled a second time to evaluate the rest of biochemical (TVB-N, TMA-N, pH), sensorial and microbiological analysis on the same individuals. Samples from both storage conditions (30 and $4^{\circ} \mathrm{C}$ ) were analyzed in triplicate at $6 \mathrm{~h}$ intervals after sacrifice, during the first day of storage, then at a daily interval for up to 5 days for the refrigerated samples only.

\section{Proximate composition and fatty acids profile}

To characterize the Algerian farmed tilapia, the moisture content of raw tilapia was determined according to ISO 1442 (1997) method. The water activity $\left(\mathrm{a}_{\mathrm{w}}\right)$ was determined by using a Thermoconstanter TH200 Novasina (Novasina, Switzerland) according to ISO 21807 (2004) method. Fat was determined according to ISO 1444 (1996) method using the Soxhlet extraction technique. The total protein content was determined according to ISO 937 ((1978) method and calculated by multiplying the total nitrogen content determined by the Kjeldahl's method by 6.25 . The ash content was carried out using the ISO 936 (1998) method. Triplicate samples of dorsal muscle were analyzed from the fresh tilapias.

To determine the fatty acid composition, total lipids of the fish muscle were first extracted using the method described by Folch et al. (1957). One hundred $\mathrm{mg}$ of fat were then used for the saponification/methylation of the fatty acids. Methylation was performed using $\mathrm{KOH} / \mathrm{MeOH}(0.5 \mathrm{~N})\left(3 \times 20 \mathrm{~min}\right.$ at $\left.70^{\circ} \mathrm{C}\right)$ followed by $\mathrm{HCl} / \mathrm{MeOH}(1 / 1 ; \mathrm{v} / \mathrm{v})\left(20 \mathrm{~min}\right.$ at $\left.70^{\circ} \mathrm{C}\right)$. Tridecanoic acid $(\mathrm{C} 13: 0)$ was used as an internal standard to quantify the fatty acids and nonadecanoic acid methyl ester (C19:0-ME) was used as injection standard. The fatty acid methyl esters (FAME) were separated by gas chromatography (Focus GC, ThermoFinnigan, USA) using a CP-Sil88 column for FAME $(100 \mathrm{~m} \times 150 \times 0.25 \mathrm{~mm}, 0.2 \mu \mathrm{m})$ (Varian Inc., USA) and analyzed with an ion trap PolarisQ mass spectrometer (MS) (ThermoFinnigan, USA).

The GC conditions were: inlet: $250^{\circ} \mathrm{C}$; splitless injection; helium as the carrier gas at $1.5 \mathrm{ml} / \mathrm{min}$; temperature program: $55^{\circ} \mathrm{C}$ for 1 $\min$, followed by an increase of $5^{\circ} \mathrm{C} \cdot \mathrm{min}^{-1}$ to $180^{\circ} \mathrm{C}$, then $10^{\circ} \mathrm{C} \cdot \mathrm{min}^{-1}$ to $200^{\circ} \mathrm{C}$ for $15 \mathrm{~min}$, then an increase of $10^{\circ} \mathrm{C} \mathrm{min}{ }^{-1}$ to $225^{\circ} \mathrm{C}$ for 12 min.; total run time was $57.50 \mathrm{~min}$. The peaks were identified by comparing their mass spectrum and retention times with those of the corresponding standards (Sigma-Aldrich, Belgium). The MS conditions were: transfer line: $250^{\circ} \mathrm{C}$; ion source: $220^{\circ} \mathrm{C}$; collision energy: $35 \mathrm{eV}$; full scan: $50-650$ from 18 to $57.50 \mathrm{~min}$. In each chromatographic run, different ions were monitored for each fatty acid analyzed, which facilitated detection and quantitative analysis. A calibration curve was performed for each of the 23 fatty acids determined. The fatty acids concentrations were determined by duplicates analysis (with a maximum variability of $10 \%$ between duplicate results) and expressed as percentage of total fatty acids.

\section{Sensory analysis}

Sensory evaluation of tilapia was carried out by three semi-trained panelists (laboratory staff) according the scheme of the Quality Index Method (QIM) of Baixas-Nogueras et al. (2003). Triplicate samples were taken from each of the two storage conditions at regular intervals. Fishes were examined physically for general appearance of skin, consistency of flesh, smell and color of gills and finally the clarity of the cornea, color of pupil and shape of eyes. Each single descriptor was associated to demerit points from 
0 to 3 (Baixas-Nogueras et al., 2003) and the range of total demerit point (score) was from 0 to 19 (19 been the acceptability limit).

\section{Microbial analysis}

Total viable counts (TVC) were determined on plate count agar (PCA) in depth at $30^{\circ} \mathrm{C}$ for $72 \mathrm{~h}$, and Enterobacteriaceae (ENT) were determined on violet red bile glucose agar (VRBG) in depth at $30^{\circ} \mathrm{C}$ for $24 \mathrm{~h}$ according to ISO methods 4833 (2003) and 21528-1 (2004), respectively. Microbiological data were expressed as logarithms of the number of colony-forming units per gram (log $\mathrm{cfu} / \mathrm{g})$.

\section{Analytical methods}

The $\mathrm{pH}$ was measured directly from tilapia's muscle using a $\mathrm{pH}$ meter Knick type 765 and a combined pH electrode (Ingold ref. 104063123) according to ISO 2917 (1999) method. Measurement was performed in three different zones of each sample and values were averaged. The TVB-N content of tilapia was extracted according to the European official method described in regulation (EC) $2074 / 2005$ then assayed by a reverse titration and expressed as $\mathrm{mg}$ TVB-N per $100 \mathrm{~g}$ tilapia flesh.

To assay specifically nitrogen generated by the TMA, the same distillation method was applied in presence of formaldehyde. Formaldehyde can block the primary and secondary amines (Malle and Tao, 1987). Hydroperoxides were determined according to the method described by Eymard and Genot (2003) and the results were expressed as mmoles of cumene hydroperoxide equivalents (mmole $\mathrm{Eq} \mathrm{CuOOH}$ ) per $\mathrm{kg}$ of wet weight. TBARS were expressed as $\mathrm{mg}$ of malonaldehyde equivalents per $\mathrm{kg}$ of wet weight (mg MDA $\mathrm{kg}^{-1}$ ) and determined according to the method of Genot (1996) which is modified from the methods of Bostoglou et al. (1994).

\section{Statistical analysis}

All data were subjected to variance analyses (ANOVA one way), and differences between means were evaluated by the Tukey test (significance $p<0.05$ ) using the statistical software SPSS 17.0 for Windows (SPSS Inc., Chicago, III., USA). The correlation between different parameters in the study was carried out by the Pearson's chi-square test. The results of statistical analysis are shown as mean values \pm standard deviation.

\section{RESULTS AND DISCUSSION}

\section{Proximate composition and fatty acid profile of tilapia (O. niloticus)}

The macronutrient composition of tilapia was $17.3 \pm 0.4 \%$ protein, $0.33 \pm 0.03 \%$ fat, $80.7 \pm 0.4 \%$ moisture and 0.59 $\pm 0.12 \%$ ash. The water activity was 0.99 indicating that fish was a favorable environment for the growth of bacteria. The total lipid percentage of Algerian farmed tilapia $(0.3 \%)$ was lower than the published data from literature whose values varied from $1.1 \pm 0.2 \%$ to $2.5 \pm$ $0.27 \%$ (De Souza et al., 2007; Suloma et al., 2008; Elagba and Al-Sabahi, 2011; Navarro et al., 2012; Dhanapal et al., 2012). The results of fatty acid profiles of Algerian farmed tilapia and tilapias fishes provided by the Research and Education Center in Aquaculture (CEFRA) are reported and compared with other fatty acid profile from literature in Table 1.

The results show that the lipid fatty acid composition varied between the different sources of tilapia. The sexual variations, fish size, season and environmental conditions, mode of breeding, rearing practices and especially the fatty acid composition of the feed influence the fatty acid content of farmed fish (De Souza et al., 2007; Elagba and Al-Sabahi, 2011; Navarro et al., 2012). Algerian Nile tilapia ( $O$. niloticus) is a good source of PUFA. The PUFA's proportion prevails and exceeds $57 \%$ of total fatty acids. This species provides an important contribution to omega-3 fatty acids intake for consumers $(18.33 \%$ of total fatty acids); most of them being eicosapentaenoic acid (EPA) and docosahe-xaenoic acid (DHA), known to prevent heart diseases and attenuate inflammatory processes (Navarro et al., 2012).

\section{Sensory assessment}

Figure 1 shows the results of the sensory analysis of tilapia (O. niloticus) stored at 4 and $30^{\circ} \mathrm{C}$. The quality of tilapia significantly declined, showing one plateau at the acceptability limit (score $=19$ ) after $12 \mathrm{~h}$ of storage at ambient temperature, and two plateaus respectively between the $6^{\text {th }}$ hour and the $24^{\text {th }} \mathrm{h}$, and between day 2 and 3 during the storage at $4^{\circ} \mathrm{C}$.

The quality of fresh fish was scored as excellent (score $=7$ ), than was judged as acceptable (score $=14$ ) until the $6^{\text {th }} \mathrm{h}$ at $30^{\circ} \mathrm{C}$ and the $3^{\text {rd }}$ day at $4^{\circ} \mathrm{C}$. After that, the quality of fish started to decrease due to formation of yellowish grey mucus, loss of pigmentation, unpleasant odors and flavors in the gills and flabby flesh. Fish were no longer acceptable and scored as inedible after 5 days at $4^{\circ} \mathrm{C}$ and only $12 \mathrm{~h}$ at $30^{\circ} \mathrm{C}$. Similar results were obtained for whole tilapia stored at ambient temperature (Adoga et al., 2010). Red tilapia (Oreochromis sp.) was scored as acceptable up to $15 \mathrm{~h}$ at $28^{\circ} \mathrm{C} \pm 2^{\circ} \mathrm{C}$ (Bakar and Izzah, 1995).

Pastoriza et al. (2008) showed similar delay (5 days) for the rejection of hake (Merluccius merliccius) under refrigerated storage. Oucif et al. (2012) reported that only three days are necessary for the rejection of the Atlantic mackerel (Scomber scombrus) conserved at $4^{\circ} \mathrm{C}$. Otherwise, most often, a delay of one week on average is granted for the refrigeration of different species of fish (Ozogul et al., 2005; Rezaei and Hosseini, 2008; Tuckey et al., 2012).

\section{Evolution of bacterial load}

The muscle of life fish is sterile. But a high load of bacteria is present on the surface of the skin, on the gills and in the digestive tract. After death, the immune system collapses allowing the bacterial proliferation. The bacteria on the skin surface colonize the scale pockets and invade the flesh during storage (Gram and Huss, 1996). Fish 
Table 1. Fatty acid profile (expressed as \% of total fatty acids) of Algerian farmed tilapia (Oreochromis niloticus), CEFRA tilapia and from literature.

\begin{tabular}{|c|c|c|c|c|c|c|c|c|}
\hline Fatty acid & & $\begin{array}{c}\text { Algerian tilapia } \\
\text { (this study) }\end{array}$ & $\begin{array}{c}\text { CEFRA tilapia } \\
\text { (this study) }\end{array}$ & $\begin{array}{c}\text { De Souza et al. } \\
(2007)\end{array}$ & $\begin{array}{c}\text { Suloma et al. } \\
(2008)\end{array}$ & $\begin{array}{c}\text { Elagba and Al-Sabahi } \\
(2011)\end{array}$ & $\begin{array}{c}\text { Navarro et al. } \\
(2012)\end{array}$ & $\begin{array}{c}\text { Dhanapal et al. } \\
(2012)\end{array}$ \\
\hline Palmitic & C16:0 & 19.4 & 23.1 & 14.8 & 23.9 & 24.2 & 24.6 & 28.3 \\
\hline Stearic & C18:0 & 10.0 & 8.2 & 5.9 & 9.2 & 22.5 & 6.2 & 8.4 \\
\hline$\Sigma$ SFA & & 29.4 & 31.3 & 23.5 & 43.2 & 64.2 & 37.3 & 46.6 \\
\hline Palmitoleic & C16:1n-7 & 1.4 & 4.8 & 1.6 & 2.2 & 12.6 & 4.3 & 9.4 \\
\hline Oleic & C18:1n-9 & 11.3 & 13.1 & 21.1 & 3.3 & 3.8 & 34.1 & 20.6 \\
\hline$\Sigma$ MUFA & & 12.7 & 17.9 & 29.5 & 12.0 & 21.5 & 41.2 & 36.0 \\
\hline Linoleic & C18:2n-6 & 13.5 & 8.5 & 29.2 & 1.4 & 1.5 & 13.3 & 9.2 \\
\hline y-Linolenic & C18:3n-6 & 1.7 & - & 1.3 & 0.4 & 0.9 & 0.3 & - \\
\hline Eicosadienoic & C20:2n-6 & 2.1 & - & 2.1 & 0.2 & 0.2 & - & - \\
\hline Eicosatrienoic & C20:3n-6 & 4.8 & 5.0 & 1.3 & 0.5 & 1.05 & - & 1.2 \\
\hline Arachidonic & C20:4n-6 & 17.4 & 7.6 & 4.0 & 9.4 & - & - & 2.0 \\
\hline$\Sigma \mathrm{n}-6$ & & 39.5 & 21.1 & 43.1 & 17.7 & 4.7 & 13.6 & 12.4 \\
\hline$\alpha$-Linolenic & C18:3n-3 & 1.8 & - & 1.2 & 0.6 & - & 0.6 & 2.4 \\
\hline Eicosapentaenoic & C20:5n-3 & 2.4 & 4.8 & - & 4.5 & - & 0.5 & 0.3 \\
\hline Docosapentaenoic & $C 22: 5 n-3$ & 3.9 & 7.8 & 0.5 & 5.1 & - & - & 0.8 \\
\hline Docosahexaenoic & C22:6n-3 & 10.3 & 17.1 & 2.0 & 16.3 & 4.0 & - & 0.9 \\
\hline$\Sigma \mathrm{n}-3$ & & 18.4 & 29.7 & 3.9 & 27.1 & 9.6 & 3.5 & 5.0 \\
\hline$\Sigma \mathrm{n}-6 / \Sigma \mathrm{n}-3$ & & 2.1 & 0.7 & 11.0 & 0.6 & 0.5 & 3.9 & 2.5 \\
\hline$\Sigma$ PUFA & & 57.9 & 50.8 & 47.0 & 44.8 & 14.3 & 17.1 & 17.4 \\
\hline
\end{tabular}

Twenty three fatty acids were measured in both Algerian and CEFRA tilapia. Only those detected in Algerian tilapia are shown. SFA, saturated fatty acids; MUFA, monounsaturated fatty acids; PUFA, polyunsaturated fatty acids; -, not detected. CEFRA: Research and Education Center in Aquaculture.

flesh has a particular nature, which make it highly susceptible for bacterial growth. The flesh have a post mortem $\mathrm{pH}$ greater than 6.0 as intrinsic factor, in addition to the important fraction of nonprotein-nitrogen (NPN) as subtract offering free amino acids, nucleotides and TMAO (Gram and Dalgaard, 2002). Microbial counts on the tilapia (O. niloticus) kept at 4 and $30^{\circ} \mathrm{C}$ are shown in Figure $2 \mathrm{~A}$ and $\mathrm{B}$, respectively. An initial total viable count (TVC) of tilapia was $3.1 \operatorname{log~cfu~g}^{-1}$ and initial enterobacteriaceae counts (ENT) of

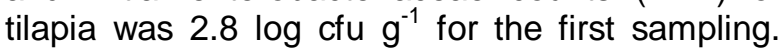

The bacterial population at $30^{\circ} \mathrm{C}$, significantly $(p<0.05)$ and rapidly increased to $7.3 \log \mathrm{cfu} \mathrm{g}^{-1}$ for TVC and to $6.8 \log \mathrm{cfu} \mathrm{g} \mathrm{g}^{-1}$ for ENT over the period of storage ( 1 day). On the other side, the bacterial evolution at $4^{\circ} \mathrm{C}$ increased slowly during the first 3 days of storage then reached a maximum of 7 log cfu $\mathrm{g}^{-1}$ for TVC and $6.3 \mathrm{log} \mathrm{cfu}$ $g^{-1}$ for ENT. A microbial safety criterion of 6 log cfu $\mathrm{g}^{-1}$ is applied for determining storage life of fresh seafood (ICMSF, 1986). The shelf-life of tilapia was thus approximately $12 \mathrm{~h}$ for ambient storage and 5 days for the refrigerated one, were the TVC loading exceeded the microbiological threshold. Our results confirm that the fish's spoilage was affected by the storage mode (Huss, 1995) and that there is a linear relationship between spoilage rate and storage temperatures. Chilling slows down microbial activities in fish relative to ambient storage. Similar results were obtained by Adoga et al. (2010) concerning the TVC loading in tilapia (O. niloticus) at ambient temperature. For the refrigerated samples, the results were consistent with the data obtained by Zhou et al. (2011) describing the preservation of whole obscure 


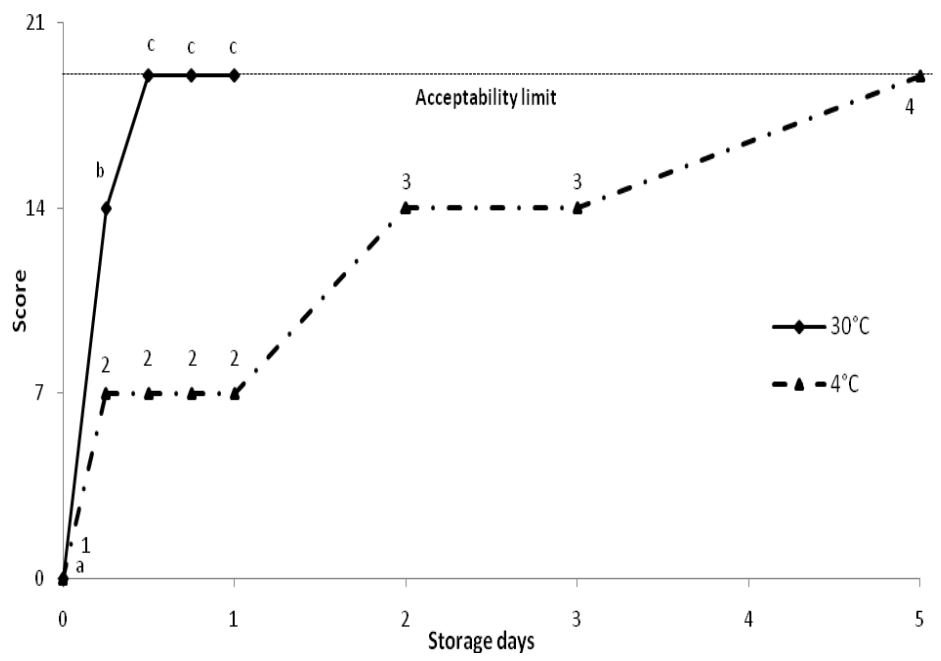

Figure 1. The sensory evaluation of tilapia (O. niloticus) stored at 30 and $4^{\circ} \mathrm{C}$, mean $\pm S D(n=3)$. Different letters/numbers on the same curve indicate a statistically significant difference (Tukey test, $p<$ 0.05). The dotted line corresponds to the acceptability limit.

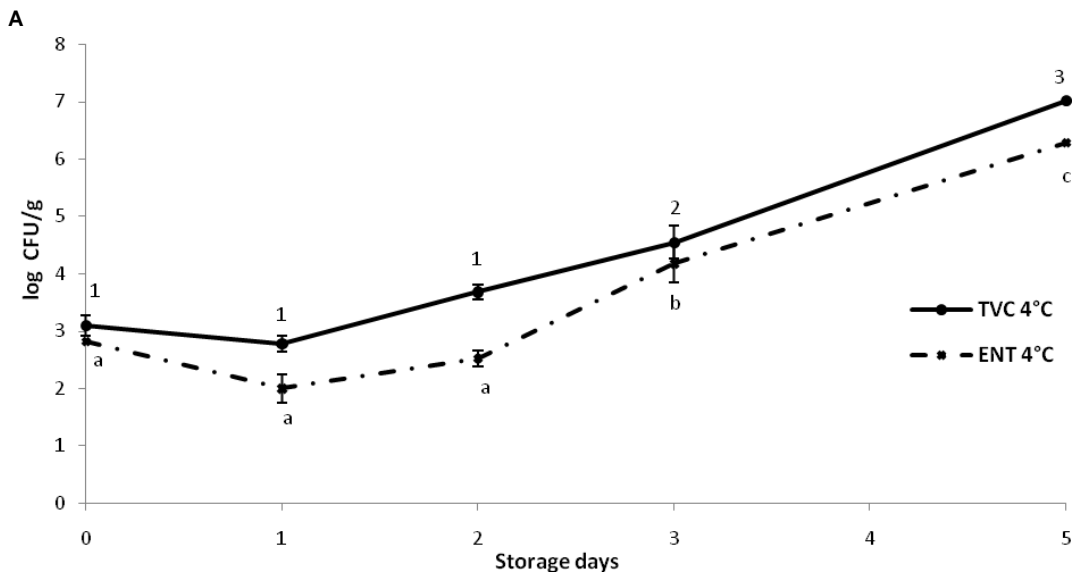

B

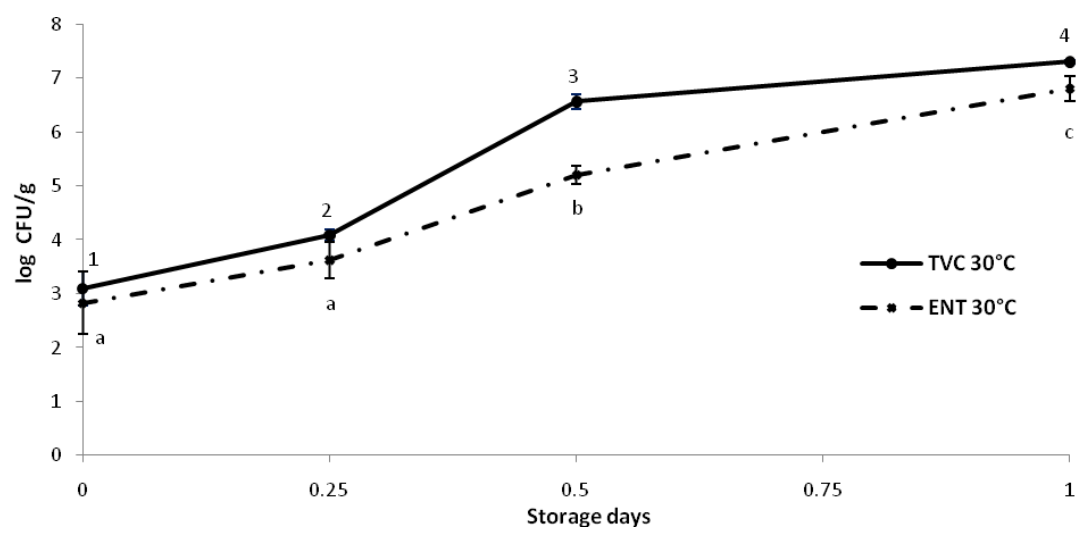

Figure 2. Changes in total viable counts (TVC) and Enterobacteriaceae (ENT) of tilapia (O. niloticus) stored at $4(2 \mathrm{~A})$ and $30^{\circ} \mathrm{C}(2 \mathrm{~B})$, mean $\pm \mathrm{SD}(\mathrm{n}=3)$. Different letters/numbers on the same curve indicate a statistically significant difference (Tukey test, $p<0.05$ ). 


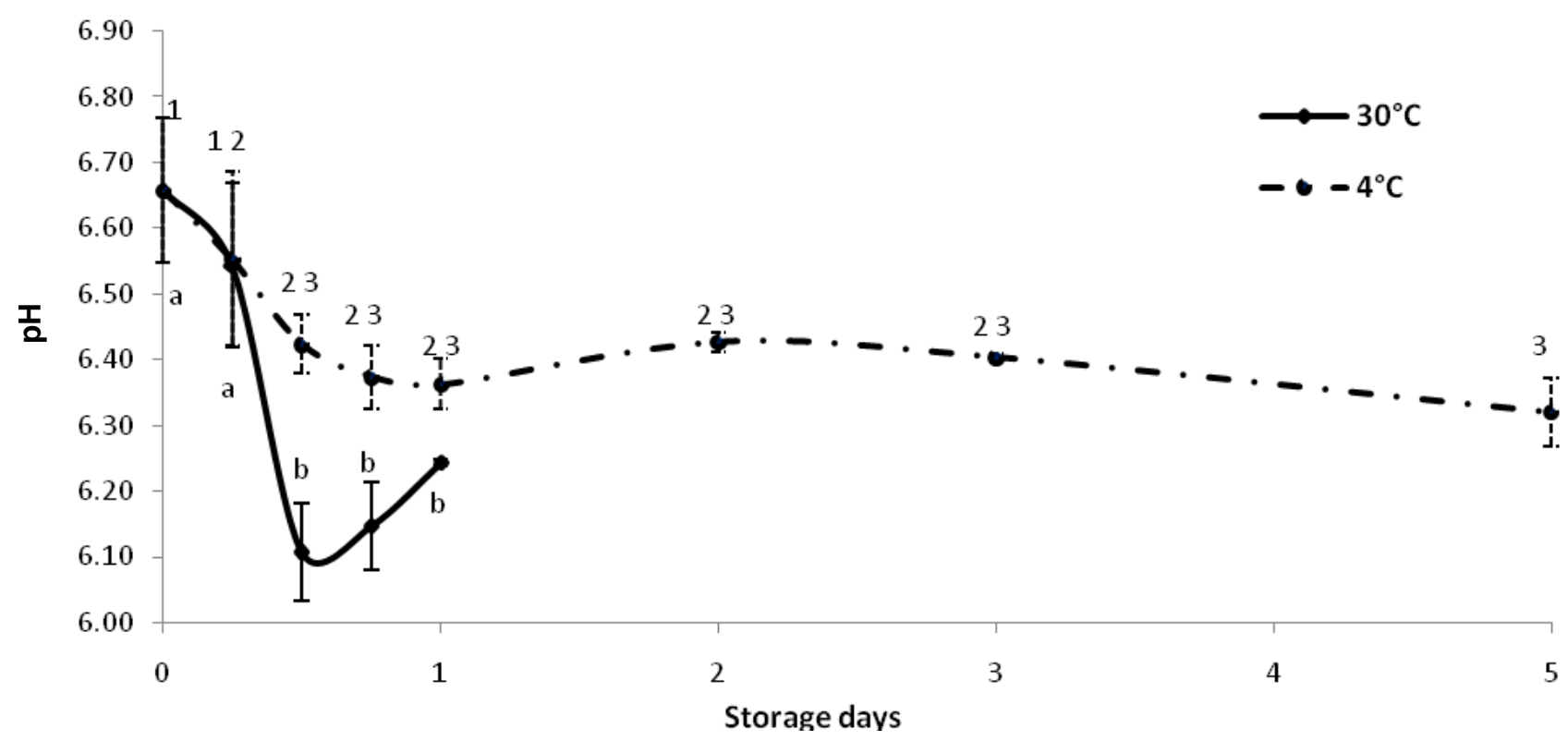

Figure 3. Changes in $\mathrm{pH}$ value of tilapia (O. niloticus) stored at 30 and $4^{\circ} \mathrm{C}$, mean $\pm \mathrm{SD}(\mathrm{n}=3)$. Different letters/numbers on the same curve indicate a statistically significant difference (Tukey test, $p<0.05$ ).

puffer fish (Takifugu obscurus) and Mexis et al. (2009) for rainbow trout (Oncorhynchus mykiss) fillets. A larger delay was allowed for others species: 7 days for hake (Merluccius merluccius) described by Pastoriza et al. (2008) and for lingcod (Ophiodon elongates) reported by Duan et al. (2010).

\section{Chemical assessment}

The initial $\mathrm{pH}$ value of $6.66 \pm 0.11$ decreased slightly $(p<0.05)$ to $6.42 \pm 0.05$ at $4^{\circ} \mathrm{C}$ and to $6.11 \pm 0.07$ at $30^{\circ} \mathrm{C}$, then remained statistically unchanged throughout the period of conservation in both storage conditions (Figure 3). Post mortem pH has been reported to vary from 6.0 to 7.1, depending on season, species and other factors (Ozogul et al., 2006). In addition, fish muscle tissue contains only very few amounts of glycogen which limit the degree of post mortem acidification of the tissue; hence the $\mathrm{pH}$ remained between 6.2-6.5 as compared to average values of the bovine meat $(\mathrm{pH} 5.5)$ (Jezek and Buchova, 2012).

TVB-N concentrations of tilapia stored at 4 and $30^{\circ} \mathrm{C}$ are presented in Figure 4A. The TMA-N values of both storage conditions are illustrated in Figure 4B. The increase in TVB-N is explained by the increased levels of its major constituents (ammonia, DMA and TMA) in the rotting tilapia. Ammonia is usually formed by bacterial deamination of amino acids as well as generated by the autolytic breakdown of adenosine monophosphate (AMP) (Shakila et al., 2003). The DMA is generated by autolysis or by the enzymatic demethylation of TMAO or TMA into
DMA and formaldehyde (Barrett, 1985). Critical limits of 30-35 mg TVB-N $100 \mathrm{~g}^{-1}$ of fish flesh were established for different groups of fish species (European Commission, 2004) and a range limit of $10-15 \mathrm{mg}$ TMA-N $100 \mathrm{~g}^{-1}$ of flesh according to fish species was recommended by Connell (1995). Our results showed that the amount of TVB-N and TMA-N increased linearly with time regardless of the storage mode. At the beginning of storage, the TVB-N value was $8.12 \pm 0.48 \mathrm{mg} 100 \mathrm{~g}^{-1}$ of flesh. This value showed gradual increase during the early stages of storage. The level increased rapidly and significantly $(p<0.05)$ to reach $35.84 \pm 0.56 \mathrm{mg}$ TVB-N $100 \mathrm{~g}^{-1}$ after $12 \mathrm{~h}$ at $30^{\circ} \mathrm{C}$ and to $37.89 \pm 0.43 \mathrm{mg}$ TVB-N $100 \mathrm{~g}^{-1}$ after 5 days at $4^{\circ} \mathrm{C}$ (Figure $4 \mathrm{~A}$ ).

Tilapia freshly sampled presented a very low content of TMA-N $\left(0.65 \pm 0.16 \mathrm{mg}\right.$ TMA-N $\left.100 \mathrm{~g}^{-1}\right)$. Then, increased significantly $(\mathrm{p}<0.05)$ and reached $8.49 \pm 0.43 \mathrm{mg}$ TMA-N $100 \mathrm{~g}^{-1}$ after $12 \mathrm{~h}$ at $30^{\circ} \mathrm{C}$ and $15.96 \pm 0.28 \mathrm{mg}$ TMA-N $100 \mathrm{~g}^{-1}$ after 5 days at $4^{\circ} \mathrm{C}$ (Figure 4B). The trend of TMA production during storage depends on the growth of spoiling bacteria. Spoiling bacteria make use of TMAO as an electron acceptor by reducing it to TMA in anaerobic conditions and generate particular ammonia-like and "fishy" off-flavors (Seibel and Walsh, 2002). Our results, at ambient temperature, agree with those of Aina et al. (2010) for TMA-N value and with those of Adoga et al. (2010) for TVB-N values for tilapia sp. The acceptance threshold value of TVB-N and TMA-N is exceeded after $12 \mathrm{~h}$ at $30^{\circ} \mathrm{C}$. The chilling conservation generally maintains the acceptability of fish within during 5 days and even more, as shown by Marrone et al. (2009) and Baixas-Nogueras et al. (2007) who reported 8 days for 
A

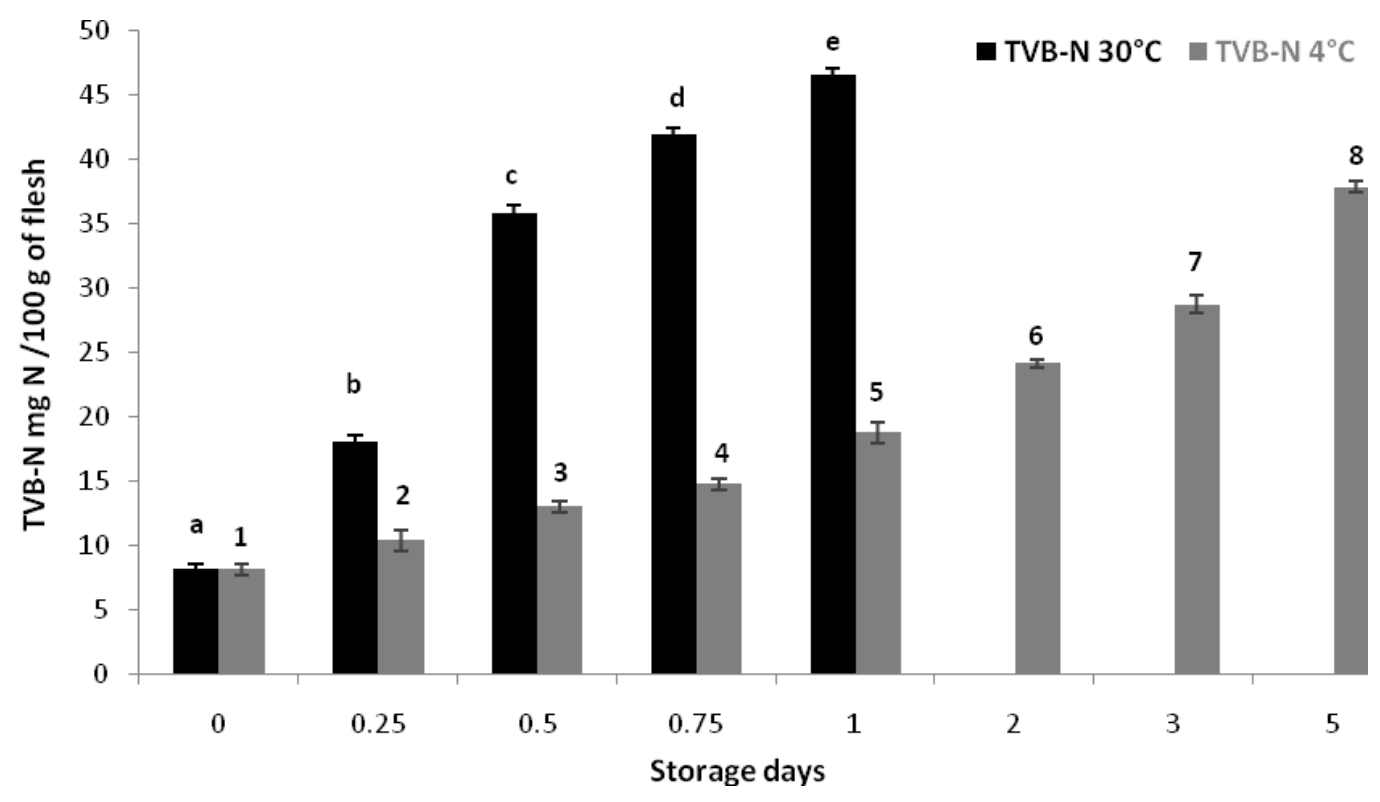

B

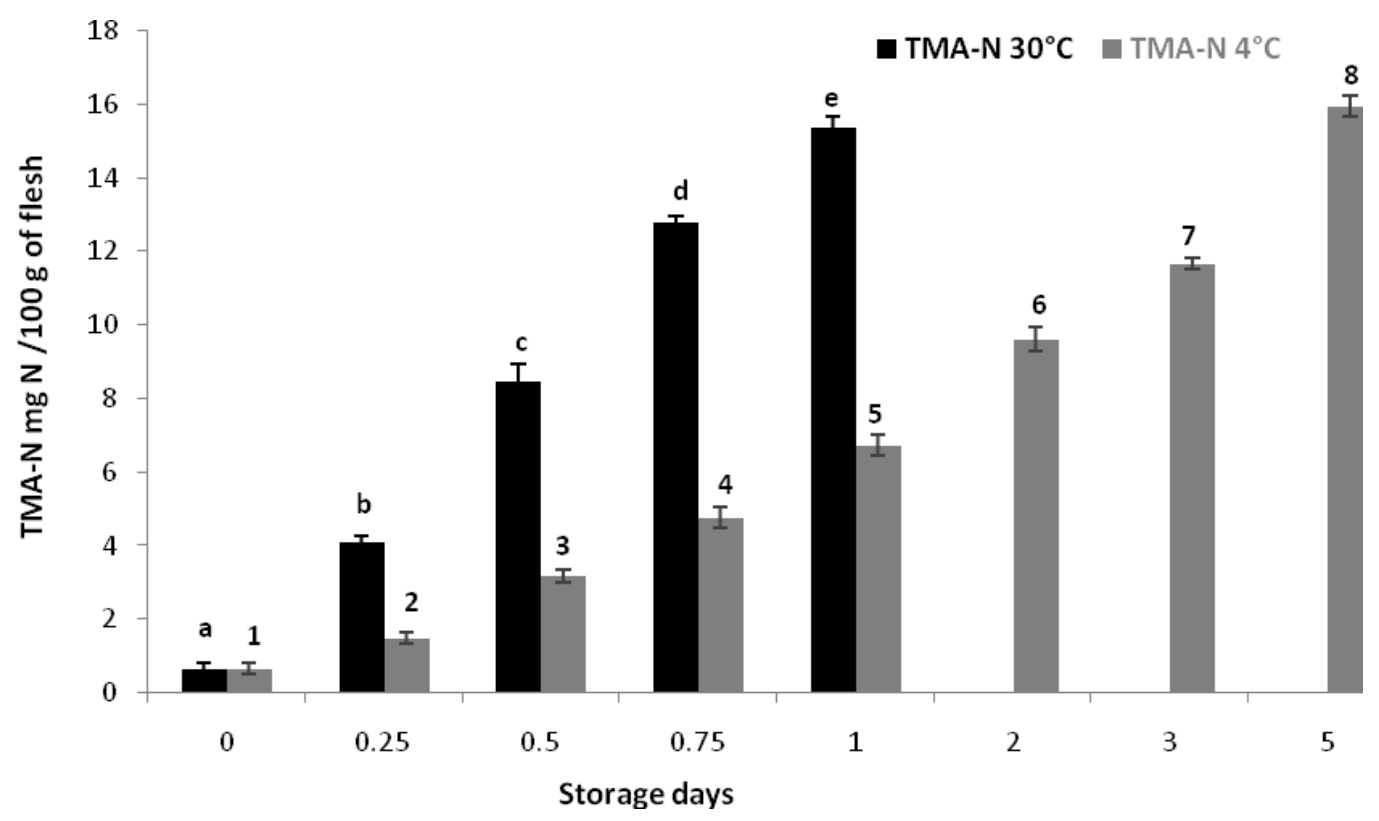

Figure 4. Changes in TVB-N (4A) and TMA-N (4B) in tilapia (O. niloticus) stored at 4 and $30^{\circ} \mathrm{C}$, mean \pm SD $(n=3)$. Different letters/numbers on the same pillars indicate a statistically significant difference (Tukey test, $p<0.05$ ).

refrigerated hake (Merluccius merluccius). These results corroborate those of sensory and bacterial assessment in which tilapia freshness was limited to $12 \mathrm{~h}$ and five days for ambient and refrigerated storage, respectively. Pearson's Chi-square test revealed a high correlation between these four parameters and the Rho value was superior to 0.82 (data not shown). We concluded that
TVB-N is a good index of tilapia freshness and TMA-N is a good spoilage index in the present study.

Levels of primary (hydroperoxides) and secondary products (TBARS) of lipid peroxidation in tilapia flesh evolved in the same way for both preservation modes (Figure 5A and B). TBARS kinetics is inversely proportional to hydroperoxides kinetics. The hydroperoxides 
A

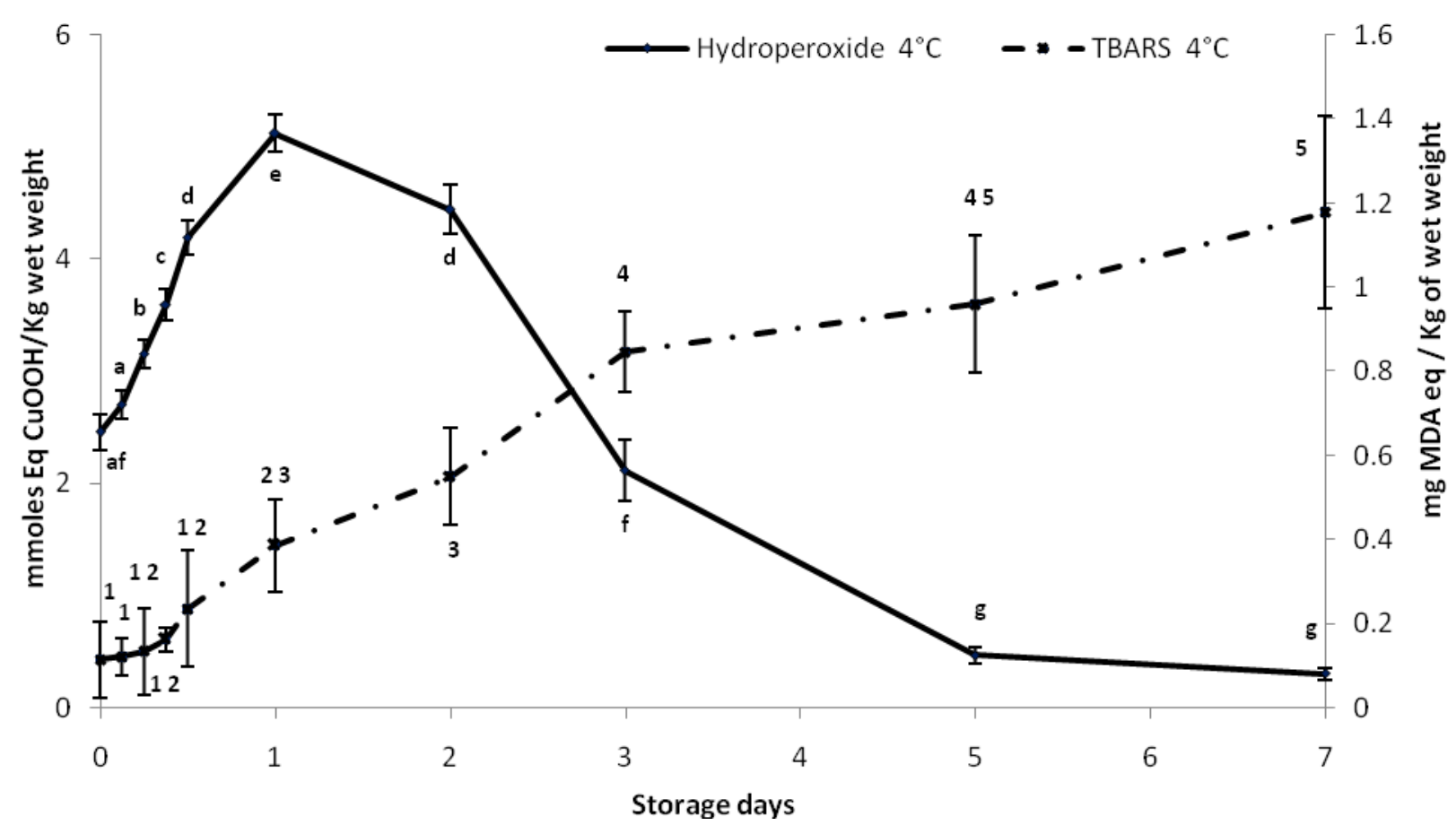

B

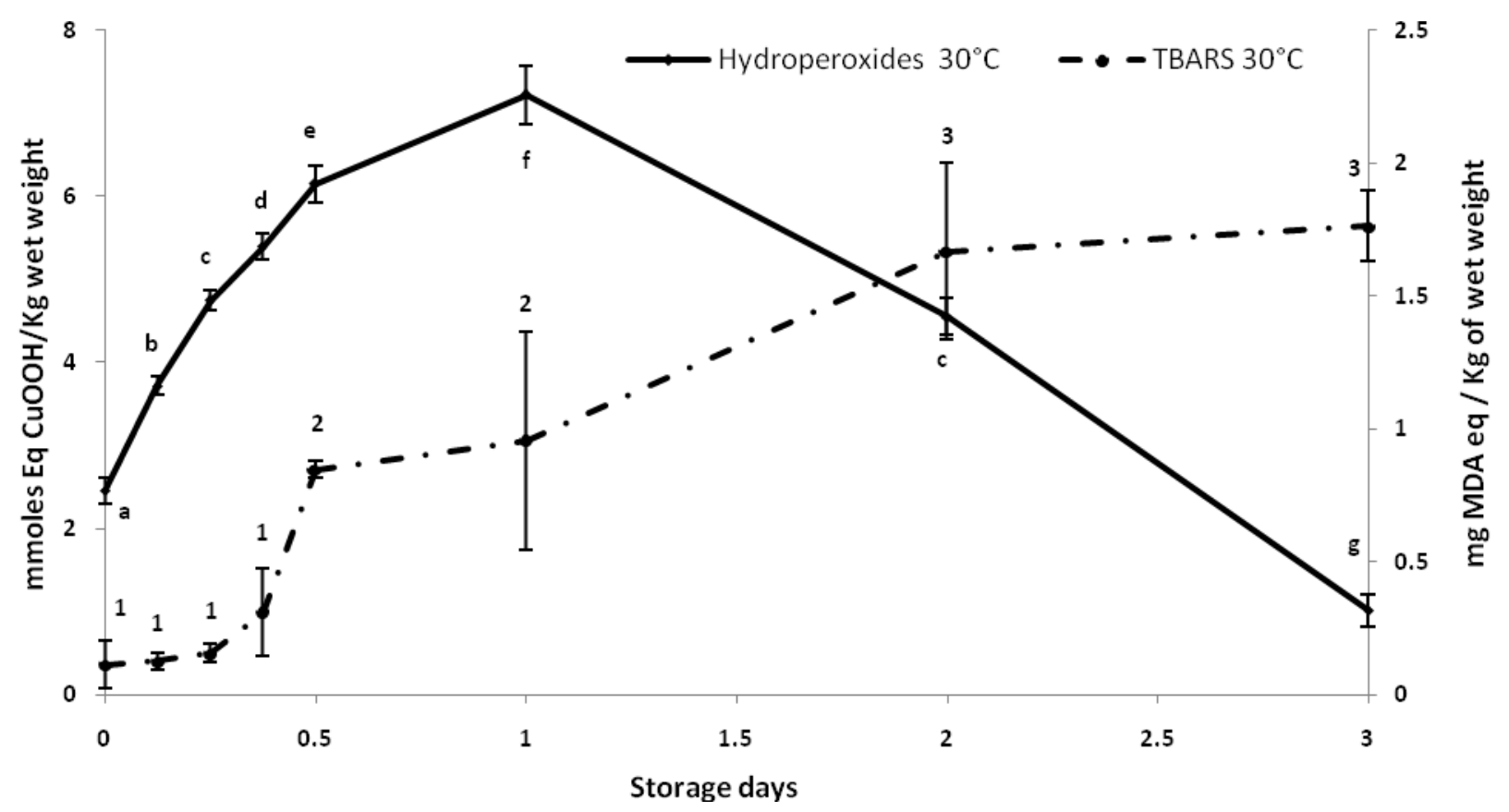

Figure 5. Changes of concentrations in hydroperoxides and TBARS, expressed per $\mathrm{kg}$ of wet weight, for samples of tilapia (O. niloticus) stored at $4^{\circ} \mathrm{C}(5 \mathrm{~A})$ and $30^{\circ} \mathrm{C}(5 \mathrm{~B})$, mean $\pm \mathrm{SD}(n=5)$. Different letters/numbers in the same curve indicate a statistically significant difference (Tukey test, $p<0.05$ ).

values increased significantly $(p<0.05)$ from an initial level of $2.46 \pm 0.16$ mmole Eq CuOOH. $\mathrm{kg}^{-1}$ to a peak of $5.12 \pm$ 0.17 mmole Eq CuOOH. $\mathrm{kg}^{-1}$ and $7.22 \pm 0.35 \mathrm{mmole} \mathrm{Eq}$
$\mathrm{CuOOH} . \mathrm{kg}^{-1}$ after $24 \mathrm{~h}$ of storage at $4^{\circ} \mathrm{C}$ (Figure $5 \mathrm{~A}$ ) and $30^{\circ} \mathrm{C}$ (Figure 5B), respectively. Then concentrations declined rapidly. This can be explained by the classic 
propagation phase of peroxidation process (Azhar and Nisa, 2006). Similar observation was also reported by Oucif et al. (2012) at the second day of storage of Atlantic mackerel (S. scombrus) using the same storage modes and analytical method. In parallel, the TBARS values remained low during the first stage of conservation, the concentrations were below $0.5 \mathrm{mg} \mathrm{MDA} \mathrm{kg}{ }^{-1}$, earlier linearly $(p<0.05)$, and increased after $12 \mathrm{~h}$ at ambient temperature (Figure $5 \mathrm{~B}$ ) and after the $3^{\text {rd }}$ day of storage at $4^{\circ} \mathrm{C}$ (Figure 5A).

A threshold value of $1 \mathrm{mg} \mathrm{MDA} \mathrm{kg}^{-1}$ is usually accepted for the rancidity of meat (Rahardjo and Sofos, 1993). In our study and for Nile tilapia, we pro-posed a threshold value of $0.85 \mathrm{mg} \mathrm{MDA} \mathrm{kg}^{-1}$ for the conservation at ambient temperature, corresponding to a value at which fish was rejected by the sensory control. The TBARS values can be a good index of tilapia freshness for both storage modes. Previous studies on Nile tilapia agree well with our findings especially for TBARS data (Bakar and Izzah, 1995; Adoga et al., 2010; Yarnpakdee et al., 2012).

\section{Conclusion}

Results of sensory, microbial (TVC), TBARS, TVB-N and TMA-N assessment are good criteria to study tilapia $(O$. niloticus) shelf life. There is a linear relationship between spoilage rate, peroxidation, storage time and storage temperatures. For consumers, we recommend a conservation of whole tilapia less than $12 \mathrm{~h}$ at ambient temperature and less than 5 days under refrigerated storage to avoid any food intoxication. Other simple method can be added such as biogenic amines assessment to corroborate these findings. The legislation and veterinary inspection services can extrapolate and translate these results to better regulate fish sales in local markets. The Algerian authorities must impose the display of fish under ice in the markets and the consumer must be sensitized on the importance of the maintenance of the cold chain for this fragile foodstuff as well.

\section{ACKNOWLEDGEMENTS}

We wish to acknowledge the contributions made by Dr. Charles Melard by providing tilapia fishes during the tests. The authors are grateful to the Averroes organization ( $3^{\text {rd }}$ program) for the granting of the doctoral award.

\section{REFERENCES}

Adoga IJ, Joseph E, Samuel OF (2010). Storage life of tilapia (Oreochromis niloticus) in ice and ambient temperature. Researcher. 2:39-44.

Aina VO, Hauwa HMS, Zakari A (2010). Comparative determination of trimethylamine in fresh fish (halibut, mudfish and tilapia). Cont. J. Fish. Aquat. Sci. 4:44-46.
Azhar KF, Nisa K (2006). Lipids and theirs oxidation in seafood. Jour. Chem. Soc. Pak. 28:298-305.

Baixas-Nogueras S, Bover-Cid S, Veciana-Nogués MT, Vidal-Carou MC (2007). Effects of previous frozen storage on chemical, microbiological and sensory changes during chilled storage of Mediterranean hake (Merluccius merluccius) after thawing. Eur. Food Res. Technol. 226:287-293.

Baixas-Nogueras S, Bover-Cid S, Veciana-Nogués T, Nunes ML., VidalCarou MC (2003). Development of a quality index method to evaluate freshness in Mediterranean hake (Merluccius merluccius). J. Food Sci. 68:1067-1071.

Bakar J, Izzah AN (1995). Sensory, biochemical and microbiological changes of farmed catfish (Clarias batrachus, Linnaeus) and red tilapia (Oreochromis sp.) at ambient storage. Pertanika J. Trop. Agric. Sci. 18:215-220.

Barrett EL (1985). Bacterial reduction of trimethylamine oxide. Annu. Rev. Microbiol. 39:131-149.

Boari CA, Pereira GI, Valeriano C, Silva BC, De Morais VM, Figueiredo HCP, Piccoli RH (2008). Bacterial ecology of tilapia fresh fillets and some factors that can influence their microbial quality. Ciênc. Tecnol. Aliment. 28:863-867.

Bostoglou NA, Fletouris DJ, Papageorgiou GE, Vassilopoulos VN, Mantis AJ, Trakatellis AG (1994). Rapid sensitive and specific thiobarbituric acid method for measuring lipid peroxidation in animal tissue, food and feedstuff samples. J. Agric. Food Chem. 42:19311937.

Connell JJ (1995). Control of fish quality . 4th edn. London: Fishing News Books.

De Souza NE, Matsushita M, De Oliveira CC, Franco MRB, Visentainer JV (2007). Manipulation of fatty acid composition of Nile tilapia (Oreochromis niloticus) fillets with flaxseed oil. J. Sci. Food Agric. 87:1677-1681.

Dhanapal KG, Reddy VS, Naik BB, Venkateswarlu G, Reddy AD, Basu $S$ (2012). Effect of cooking on physical, biochemical, bacteriological characteristics and fatty acid profile of tilapia (Oreochromis mossambicus) fish steaks. Arch. Appl. Sci. Res. 4:1142-1149.

Duan J, Cherian G, Zhao Y (2010). Quality enhancement in fresh and frozen lingcod (Ophiodon elongates) fillets by employment of fish oil incorporated chitosan coatings. Food Chem. 119:524-532.

Elagba HAM, Al-Sabahi GN (2011). Fatty acids content and profile of common commercial Nile fishes in Sudan. Int. J. Fish. Aquaculture. 3:99-104.

European.Commission (2004). Commission regulation 2074/2005 of 5 december 2005 laying down implementing measures for certain products under regulation (EC) $\mathrm{N}^{\circ} 853 / 2004$ of the European parliament and of the council and for the organisation of official controls under regulation (EC) $\mathrm{N}^{\circ} 854 / 2004$ of the European parliament and of the council and regulation (EC) $N^{\circ} 882 / 2004$ of the European parliament and of the council, derogating from regulation (EC) $\mathrm{N}^{\circ} 852 / 2004$ of the European parliament and of the council and amending regulations (EC) $\mathrm{N}^{\circ} 853 / 2004$ and (EC) $\mathrm{N}^{\circ} 854 / 2004$. Off. J. Eur. Union. L 338:27-59.

Eymard S, and Genot C (2003). A modified xylenol orange method to evaluate formation of lipid hydroperoxides during storage and processing of small pelagic fish. Eur. J. Lipid Sci. Technol. 105:497501.

FAO (2012). The state of world fisheries and aquaculture 2012. Rome. p. 209.

Folch J, Lees M, Sloane Stanley GH (1957). A simple method for the isolation and purification of total lipides from animal tissue. J. Biol. Chem. 226:497-509.

Genot C (1996). Some factors influencing TBA test. Annual report of the $5^{\text {th }}$ PCRD EU project: Dietary treatment and oxidative stability of muscle and meat products: nutritive value, sensory quality and safety (Diet-ox), AIR III-CT-92-1577.

Gram L, Dalgaard P (2002). Fish spoilage bacteria - problems and solutions. Curr. Opin. Biotechnol. 13:262-266.

Gram L, Huss HH (1996). Microbiological spoilage of fish and fish products. Int. J. Food Microbiol. 33:121-137.

Huss HH (1995). Quality and quality changes in fresh fish. FAO fisheries technical paper $N^{\circ}$. 348, Food and Agriculture Organization (FAO) of the United Nations, Rome, Italy. 
ICMSF (1986). International commission on microbiological specifications for foods. sampling plans for fish and shellfish. In: ICMSF ( $2^{\text {nd }}$ ed.), Microorganisms in foods. Sampling for microbiological analysis: Principles and scientific applications, vol. 2. University of Toronto Press: Toronto, Canada.

ISO 936 (1998). Meat and meat products. Determination of total ash. International standard, $2^{\text {nd }}$ ed. Available at http://www.iso.org/iso/publcation_item.htm?pid=PUB100042.

ISO 937 (1978). Meat and meat products. Determination of nitrogen content -reference method. International standard, $1^{\text {st }}$ ed.

ISO 1442 (1997). Meat and meat products. Determination of moisture content -reference method. International standard, $2^{\text {nd }}$ ed.

ISO 1444 (1996). Meat and meat products. Determination of free fat content. International standard, $2^{\text {nd }}$ ed.

ISO 2917 (1999). Meat and meat products. Measurement of $\mathrm{pH}$ reference method. International standard, $2^{\text {nd }} \mathrm{ed}$.

ISO 4833 (2003). Microbiology of food and animal feeding stuffs. Horizontal method for the enumeration of microorganisms -Colonycount at 30 degrees $\mathrm{C}$ by the pour plate technique. International standard, $3^{\text {rd }}$ ed.

ISO 21528-1 (2004). Microbiology of food and animal feeding stuffs Horizontal methods for the detection and enumeration of Enterobacteriaceae -Part 1: Detection and enumeration by MPN technique with pre-enrichment. International standard, $1^{\text {st }}$ ed.

ISO 21807 (2004). Microbiology of food and animal feeding stuffs Determination of water activity. International standard, $1^{\text {st }}$ ed.

Jezek F, Buchova H (2012). Shelf-life of freeze-thawed fillets of common carp (Cyprinus carpio L.) and silver carp (hypophthalmichthys molitrix V.) packed under air. Acta. Agr. Slov. 3:275-279.

Malle P, Tao SH (1987). Rapid quantitative determination of trimethylamine using stream distillation. J. Food Pro. 50:756-760.

Marrone R, Vollano L, Chirollo C, Palma G, Mercogliano R (2009). Shelf life of different fish species stored with passive refrigeration (PRS). Vet. Res. Commun. 33:241-243.

Mexis SF, Chouliara E, Kontominas MG (2009). Combined effect of an oxygen absorber and oregano essential oil on shelf life extension of rainbow trout fillets stored at $4^{\circ} \mathrm{C}$. Food Microbiol. 26:598-605.

Navarro RD, Navarro FKSP, Filho OPR, Ferreira WM, Pereira MM, Filho JTS (2012). Quality of polyunsaturated fatty acids in Nile tilapias (Oreochromis niloticus) fed with vitamin E supplementation. Food Chem. 134:215-218.

Niizeki N, Daikoku T, Hirata T, El-Shourbagy I, Song X, Sakaguchi M (2003). Mechanism of biosynthesis of trimethylamine oxide in tilapia reared under seawater conditions. Fisheries Sci. 69:74-87.

Oucif H, Ali-Mehidi S, Abi-Ayad S-MEA (2012). Lipid oxidation and histamine production in Atlantic mackerel (Scomber scombrus) versus time and mode of conservation. J. Life Sci. 6:713-720.

Ozogul Y, Boga KE, Tokur B, Ozogul F (2011). Changes in biochemical, sensory and microbiological quality indices of common sole (Solea solea) from the Mediterranean sea, during ice storage. Turk. J. Fish. Aquat. Sci. 11:243-251.

Ozogul Y, Ozogul F, Kuley E, Ozkutuk S, Gokbulut C, Kose S (2006). Biochemical, sensory and microbiological attributes of wild turbot (Scophthalmus maximus), from the Black sea, during chilled storage. Food Chem. 99:752-758.
Ozogul Y, Ozyurt G, Ozogul F, Kuley E, Polat A (2005). Freshness assessment of European eel (Anguilla anguilla) by sensory, chemical and microbiological methods. Food Chem. 92:745-751.

Pastoriza L, Bernardez M, Sampedro G, Cabo ML, and Herrera JJR (2008). Use of sterile and ozonized water as a strategy to stabilize the quality of stored refrigerated fresh fish. Food Control. 19:772-780.

Rahardjo S, Sofos JN (1993). Methodology for measuring malonaldehyde as a product of lipid peroxidation in muscle tissues: a review. Meat Sci. 35:145-169.

Rezaei M, Hosseini SF (2008).Quality assessment of farmed rainbow trout (Oncorhynchus mykiss) during chilled storage. J. Food Sci. 73:93-96.

Seibel BA, Walsh PJ (2002). Trimethylamine oxide accumulation in marine animals: relationship to acylglycerol storage. J. Exp. Biol. 205:297-306

Shakila RJ, Vijayalakshmi K, Jeyasekaran G (2003). Changes in histamine and volatile amines in six commercially important species of fish of the Thoothukkudi coast of Tamil Nadu, India stored at ambient temperature. Food Chem. 82:347-352.

Suloma A, Ogata HY, Garibay ES, Chavez DR, El-Haroun ER (2008). Fatty acid composition of Nile tilapia Oreochromis niloticus muscles: a comparative study with commercially important tropical freshwater fish in Philippines. $8^{\text {th }}$ Int. Symp. Tilapia Aquaculture. 921-932.

Tuckey NPL, Forgan LG, Jerrett AR (2012). Fillet colour correlates with biochemical status in Australasian snapper (Pagrus auratus) during storage in refrigerated seawater. Aquaculture. 356:256-263.

Yarnpakdee S, Benjakul S, Nalinanon S, Kristinsson HG (2012). Lipid oxidation and fishy odour development in protein hydrolysate from Nile tilapia (Oreochromis niloticus) muscle as affected by freshness and antioxidants. Food Chem. 132:1781-1788.

Zhou R, Liu Y, Xie J, Wang X (2011). Effects of combined treatment of electrolysed water and chitosan on the quality attributes and myofibril degradation in farmed obscure puffer fish (Takifugu obscurus) during refrigerated storage. Food Chem. 129:1660-1666. 